DOI: https://doi.org/10.24127/ajpm.v9i2.2695

\title{
KEMAMPUAN REPRESENTASI MATEMATIS FIELD INTERMEDIATE DALAM MENYELESAIKAN SOAL ETNOMATEMATIKA
}

\author{
Himmatul Ulya ${ }^{1 *}$, Ratri Rahayu ${ }^{2}$ \\ ${ }^{1 * 2}$ Universitas Muria Kudus, Kudus, Indonesia \\ *Corresponding author. Gondangmanis, PO. BOX 53, 59327, Kudus, Indonesia. \\ E-mail: $\quad$ himmatul.ulya@umk.ac.id ${ }^{\left.{ }^{*}\right)}$ \\ ratri.rahayu@umk.ac.id $^{21}$
}

Received 20 February 2020; Received in revised form 06 June 2020; Accepted 20 June 2020

\begin{abstract}
Abstrak
Penelitian ini bertujuan untuk menganalisis kemampuan representasi matematis siswa dengan gaya kognitif Field Intermediate (FDI) dalam menyelesaikan soal etnomatematika di SD 1 Muhammadiyah Kudus. Penelitian ini merupakan penelitian deskriptif kualitatif. Subjek penelitian adalah tiga siswa kelas III SD 1 Muhammadiyah Kudus yang memiliki gaya kognitif FDI. Tiga siswa tersebut tergolong dalam FDI lemah, sedang, dan kuat. Analisis data dalam penelitian ini menggunakan teknis analisis yang mengacu pada Miles dan Huberman, yaitu reduksi data, penyajian data, dan penarikan simpulan. Jawaban siswa pada TRM dianalisis dan subjek penelitian diwawancara sebagai triangulasi. Langkah selanjutnya yaitu menganalisis data kemampuan representasi siswa dari subjek FDI. Hasil dari penelitian menunjukkan bahwa profil representasi matematis siswa FDI tergolong baik, tetapi masih banyak kendala yang dihadapi. dalam representasi visual, siswa belum dapat menyajikan kembali data atau informasi dari suatu representasi ke representasi tabel; dalam representasi simbolik, siswa belum dapat membuat konjektur dari suatu pola bilangan; dan dalam representasi verbal, siswa belum dapat membuat situasi masalah berdasarkan data atau representasi yang diberikan, dan belum dapat menyusun langkah-langkah penyelesaian masalah matematis dengan kata-kata.
\end{abstract}

Kata kunci: field intermediate; gaya kognitif; kemampuan representasi matematis; soal etnomatematika.

\begin{abstract}
This study aims to analyze the mathematical representation ability of students with the Field Intermediate (FDI) cognitive style in solving ethnomathematics problems at SD 1 Muhammadiyah Kudus. This research is a qualitative descriptive study. The research subjects were three third grade students of SD 1 Muhammadiyah Kudus who had FDI cognitive styles. The three students were classified as low, medium, and high FDI. Data analysis in this study uses technical analysis that refers to Miles and Huberman, namely data reduction, data presentation, and drawing conclusions. Students' answers on TRM were analyzed and research subjects were interviewed as triangulation. The next step is to analyze the student's representation ability data from the subject of FDI. The results of the study showed that the FDI students' mathematical representation profile was good, but there were still many obstacles encountered. in visual representation, students have not been able to restate data or information from a representation to the table representation; in symbolic representation, students have not been able to make a conjecture of a number pattern; and (3) in verbal representations, students have not been able to create problem situations based on data or representations provided, and have not been able to arrange steps to solve mathematical problems with words.
\end{abstract}

Keywords: Cognitive style; ethnomathematics problem; field intermediate; mathematics representation ability

\section{PENDAHULUAN}

Kemampuan

matematis merupakan salah satu

kemampuan matematis yang penting

untuk dimiliki siswa. Representasi matematis akan selalu muncul saat siswa mempelajari matematika. Siswa dapat merepresentasikan matematika melalui ide-ide matematika yang dimiliki (Minarni, Napitupulu, \& 
Husein, 2016). Gagasan matematis diungkapkan dengan berbagai cara, antara lain dengan melalui gambar, grafik, diagram, cara lisan dan tulisan dengan simbol-simbol matematika. Representasi matematis digunakan untuk menemukan dan menciptakan suatu cara berpikir dalam menyampaikan ide dan gagasan matematis yang bersifat abstrak menjadi lebih konkret sehingga dapat menjadi lebih mudah dipahami (Effendi, 2012).

Kemampuan representasi matematis siswa dapat dipetakan berdasarkan gaya kognitif. Setiap individu memiliki kekhasan atau karakteristik dalam berpikir, mengolah informasi, dan menanggapi tugas yang disebut gaya kognitif (Brown, Brailsford, Fisher, Moore, \& Ashman, 2006; Kozhevnikov, 2007). Gaya kognitif dari setiap individu yang berbeda menyebabkan perbedaan pada kemampuan representasinya juga (Azizah, L. N., Junaidi, I., 2019).

Menurut pakar psikologi dan pendidikan, gaya kognitif digolongkan menjadi dua, yaitu Field Independent (FI) dan Field Dependent (FD). Individu yang memiliki gaya kognitif FD cenderung menerima suatu pola sebagai suatu keseluruhan (Ngilawajan, 2013). Kelompok FD membutuhkan petunjuk untuk menyelesaikan suatu permasalahan. Sebaliknya, siswa FI memiliki kemampuan lebih baik dalam menganalisis informasi kompleks dan tidak terstruktur. Individu dengan gaya kognitif FI dapat menyelesaikan permasalahan yang memerlukan analisis dalam pemecahannya (Akramunnisa, Tahmir, \& Dassa, 2017). Di antara FI dan FD terdapat suatu gaya kognitif sebagai penengah keduanya, yaitu gaya kognitif Field Intermediate (FDI). Siswa FDI cenderung memiliki karakter seperti FI atau FD (Ulya, Kartono, \& Retnoningsih, 2014).

Pentingnya kepemilikan representasi tidak sesuai dengan fakta di lapangan yang menunjukkan kemampuan siswa sekolah dasar (SD) dalam representasi matematika termasuk dalam kriteria rendah (Mahardiyanti, 2014). Oleh sebab itulah guru perlu menganalisis profil kemampuan representasi matematis siswa sebagai acuan dalam memperbaiki pembelajaran.

Sebagai langkah perbaikan pembelajaran matematika, guru hendaknya dapat membantu siswa untuk meningkatkan kemampuan representasi matematisnya, sehingga akan memberikan pengaruh terhadap hasil belajar siswa yang meningkat. Guru matematika harus mampu menerjemahkan matematika yang dianggap rumit oleh siswa, menjadi bentuk yang mudah dipahami oleh siswa (Permata, J. I., Sukestiyarno, Y. L., \& Hindarto, 2017).

Namun faktanya, pembelajaran matematika belum diarahkan agar siswa dapat menerapkan konsep untuk memecahkan masalah dalam kehidupan sehari-hari dan mengkomunikasikan pendapatnya dalam menyelesaikan permasalahan matematika. Siswa belajar matematika sebatas menghafalkan konsep tanpa memahami maksudnya (Hendriana, 2012). Pembelajaran matematika masih didominasi oleh pengenalan konsep dan rumus tanpa ada perhatian terhadap pemahaman siswa (Siswono, 2012).

$$
\text { Selain }
$$

permasalahan pembelajaran matematika yang belum diarahkan agar siswa dapat menerapkan konsep untuk memecahkan masalah dalam kehidupan sehari-hari, proses pembelajaran matematika selama ini juga tidak dikaitkan dengan budaya. 
Pembelajaran matematika yang bernuansa budaya akan membuat pembelajaran matematika lebih bermakna dan bermanfaat untuk meningkatkan aspek kognitif dan afektif siswa (Arisetyawan, Suryadi, Herman, \& Rahmat, 2014; Ulya \& Rahayu, 2017). Tidak hanya dalam pelaksanaan pembelajaran, budaya yang dikaitkan dengan matematika juga dapat dijadikan sebagai alat evaluasi terhadap siswa. Proses pembelajaran dan evaluasi yang mengaitkan materi dengan budaya akan mendorong siswa untuk mengaitkan pengetahuan yang dimiliki dengan budaya dan permasalahan dalam kehidupan nyata sehingga diharapkan siswa dapat menyelesaikan masalah representasi matematis menjadi lebih mudah.

Permasalahan pembelajaran yang terjadi selama ini harus diselesaikan oleh guru agar kemampuan representasi matematis siswa lebih mendapatkan perhatian. Apabila pembelajaran matematika yang monoton dan prosedural dibiarkan, maka akan berdampak pada hasil belajar matematika yang kurang memuaskan. Selain itu, pembelajaran matematika di sekolah tidak dibiasakan untuk menggunakan soal-soal berpikir tingkat tinggi juga akan berdampak pada kesulitan siswa memecahkan masalah yang menuntut berpikir tidak rutin seperti pada soal-soal The Third International Mathematics and Science Study (TIMSS) dan Programme for International Student Assessment (PISA). Hal ini diperkuat dari hasil evaluasi TIMSS tahun 2015 dan PISA tahun 2018 yang menunjukkan bahwa Indonesia menduduki peringkat 6 terbawah terbawah (Mullis, Martin, Foy, \& Hooper, 2015; OECD, 2019).

Berdasarkan keterangan dari salah satu guru di SD Muhammadiyah 1
Kudus diperoleh hasil bahwa kemampuan representasi matematis siswa masih tergolong rendah. Hal ini disebabkan oleh guru tidak membiasakan siswa dengan soal yang mengukur kemampuan representasi matematisnya. Sebagian besar siswa mengalami hambatan dalam menyelesaikan masalah representasi matematis. Siswa mengalami kesulitan yang beragam, diantaranya kesulitan dalam memahami soal, membuat ilustrasi gambar dari permasalahan, mengubah variabel ke dalam model matematika, menerapkan konsep untuk menyelesaikan masalah, serta menyajikan penyelesaian masalah. Hal ini diperkuat hasil penelitian yang menunjukkan bahwa pada aspek representasi verbal siswa hanya mencapai $41,2 \%$, aspek representasi simbol mencapai 28,1\%, dan pada aspek represntasi visual mencapai $34,6 \%$ yang berarti masuk kategori sangat rendah (Handayani \& Juanda, 2018).

Pada penelitian sebelumnya telah ada yang mengungkapkan profil penalaran siswa SD ditinjau dari gaya kognitif (Sari, Juniati, \& Lukito, 2014). Siswa FI memiliki kemampuan penalaran yang lebih baik daripada siswa FD. Selain itu, penelitian lain telah menganalisis profil kemampuan representasi matematis siswa berdasarkan kemampuan matematisnya (Manurung \& Kartono, 2016). Kemampuan representasi tersebut diuraikan berdasarkan indikator visual, simbolik, dan verbal. Dalam penelitian sebelumnya hanya berfokus pada siswa dengan gaya kognitif FI dan FD, sehingga perlu dilakukan penelitian lebih lanjut untuk mendeskripsikan kemampuan representasi matematis siswa berdasarkan indikator representasi visual, simbolik, dan verbal khususnya 
siswa dengan gaya kognitif FDI dalam menyelesaikan soal etnomatematika. Penelusuran terhadap kemampuan representasi matematis merupakan salah satu usaha yang dapat dilakukan guru untuk mengatasi kesulitan belajar siswa. Dengan mengetahui profil kemampuan representasi matematis siswa berdasarkan gaya kognitif, guru dapat menyiapkan strategi khusus dalam pelaksanaan pembelajaran agar kemampuan representasi matematis siswa dapat berkembang menjadi lebih baik.

Berdasarkan latar belakang tersebut, maka tujuan penelitian ini yaitu: mendeskripsikan kemampuan representasi matematis siswa dengan gaya kognitif Field Intermediate dalam menyelesaikan soal etnomatematika di SD 1 Muhammadiyah Kudus.

\section{METODE PENELITIAN}

Jenis penelitian yang digunakan dalam penelitian ini adalah penelitian deskriptif kualitatif. Penelitian ini dilakukan di SD 1 Muhammadiyah Kudus. Penelitian dilaksanakan di kelas III pada semester genap tahun pelajaran 2017/2018. Subjek penelitian adalah tiga siswa kelas III yang memiliki gaya kognitif FDI. Tiga siswa tersebut diambil dari perwakilan gaya kognitif FDI tertinggi, sedang, dan terendah. Penetapan subjek dalam penelitian ini berpedoman pada hasil tes gaya kognitif. Subjek dipilih dengan melihat skor hasil tes Group Embedded Figures Test (GEFT).

Teknik pengumpulan data dalam penelitian ini melalui teknik tes dan teknik non tes. Teknik tes digunakan untuk mendapatkan data hasil pekerjaan siswa dalam representasi matematis, sedangkan teknik non tes berupa wawancara. Wawancara dilakukan untuk triangulasi teknik, yaitu membandingkan dan mengecek kembali suatu informasi yang diperoleh melalui teknik yang berbeda sehingga kredibilitas data didapatkan.

Teknik analisis data yang digunakan dalam penelitian ini mengacu pada pendapat Miles dan Huberman, yaitu melalui reduksi data, penyajian data, dan penarikan simpulan. Reduksi data merupakan kegiatan yang mengacu pada proses pemilihan dan pengidentifikasian data yang memiliki makna jika dikaitkan dengan pertanyaan penelitian. Penyajian data dalam penelitian ini digunakan untuk melihat gambaran keseluruhan hasil penelitian mengenai kemampuan representasi matematis siswa. Dari data hasil reduksi dan penyajian data selanjutnya ditarik suatu simpulan dan verifikasi data sehingga ditemukan kebermaknaan data sebagai tujuan penelitian.

\section{HASIL DAN PEMBAHASAN}

\section{Profil Kemampuan Representasi Matematis Siswa FDIL}

Subjek Field Intermediate Lemah (FDIL) FDIL adalah subjek FDI yang memiliki skor GEFT terendah dalam kategori FDI. Skor GEFT yang diperoleh subjek FDIL adalah 10. Berikut ini adalah penjelasan lebih rinci dari kemampuan representasi matematis subjek FDIL dalam menyelesaikan soal etnomatematika.

1. Representasi Visual

Subjek FDIL belum dapat menyajikan kembali data atau informasi dari suatu representasi ke dalam bentuk tabel. FDIL dapat memanfaatkan representasi visual untuk menyelesaikan masalah tetapi proses penyelesaiannya belum sistematis. Dalam menggambar pola-pola geometri, subjek FDIL hanya dapat membuat satu gambar. Siswa dapat membuat gambar bangun geometri berdasarkan permasalahan 
kemudian gambar tersebut digunakan sebagai media untuk mempermudah melakukan penyelesaian. Gambar 1 adalah contoh hasil pekerjaan subjek FDIL dalam merepresentasikan matematis secara visual.

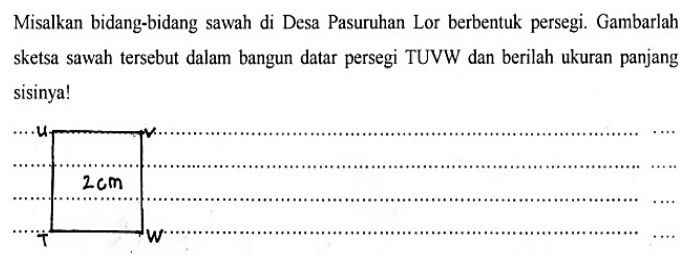

Gambar 1. Hasil pekerjaan subjek FDIL dalam representasi visual.

Pada saat wawancara dilakukan, subjek FDIL bingung untuk menyajikan suatu representasi ke dalam bentuk tabel. FDIL merasa terbantu dengan adanya visualisasi permasalahan di dalam soal. Namun, FDIL belum dapat membuat proses penyelesaiannya secara sistematis. Subjek FDIL hanya membuat satu gambar ketika diminta untuk membuat pola-pola geometri. FDIL dapat menggambar bangun geometri berdasarkan permasalahan kemudian gambar tersebut untuk memfasilitasi dirinya untuk menyelesaikan masalah.

Berdasarkan hasil pekerjaan tertulis dan wawancara dari subjek FDIL dalam representasi visual menunjukkan ciri-ciri seperti pada Tabel 1.

Tabel 1. Representasi visual subjek FDIL.

\begin{tabular}{cl}
\hline No & \multicolumn{1}{c}{ Keterangan } \\
\hline 1. & $\begin{array}{l}\text { Belum mampu menyajikan ulang data dari } \\
\text { suatu representasi ke representasi tabel }\end{array}$ \\
2. & $\begin{array}{l}\text { Mampu memanfaatkan representasi visual } \\
\text { untuk memecahkan masalah tetapi belum } \\
\text { dapat menyusun proses penyelesaiannya }\end{array}$ \\
secara sistematis & Dapat membuat satu gambar pola \\
geometri & $\begin{array}{l}\text { Dapat menggambar bangun geometri } \\
\text { untuk membantu memvisualisasikan } \\
\text { permasalahan dan untuk memfasilitasi } \\
\text { pemecahan masalah }\end{array}$
\end{tabular}

Copyright (C) 2020, Universitas Muhammadiyah Metro

\section{Representasi Simbolik}

Subjek FDIL dapat menyusun persamaan atau model matematika dari representasi verbal yang diketahui. FDIL belum dapat membuat konjektur dari suatu pola bilangan. Dalam melakukan penyelesaian masalah yang melibatkan ekspresi matematis, subjek FDIL belum dapat menyusun secara sistematis. Gambar 2 adalah contoh hasil pekerjaan subjek FDIL dalam merepresentasikan matematis secara simbolik.

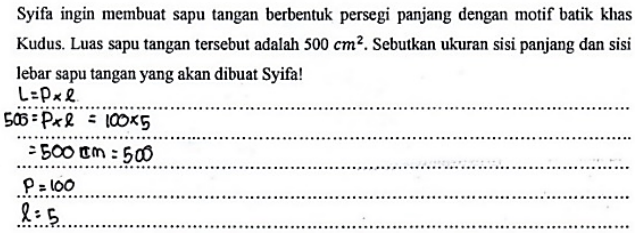

Gambar 2. Hasil pekerjaan subjek FDIL dalam representasi simbolik.

Pada saat wawancara dilakukan, subjek FDIL dapat menyusun persamaan atau model matematika dari suatu representasi verbal walaupun perlu berulang kali untuk memahami permsalahan. FDIL bingung untuk membuat konjektur dari suatu pola bilangan. FDIL berusaha mencoba menyelesaikan masalah berkaitan dengan membuat konjektur dari suatu pola bilangan tetapi belum tepat. Subjek FDIL belum dapat menyusun penyelesaian dengan melibatkan ekspresi matematis secara sistematis.

Tabel 2. Representasi simbolik subjek FDIL

\begin{tabular}{cl}
\hline No & \multicolumn{1}{c}{ Keterangan } \\
\hline 1. & $\begin{array}{l}\text { Dapat menyusun persamaan atau model } \\
\text { matematika dari representasi lain yang } \\
\text { diketahui }\end{array}$ \\
2. & $\begin{array}{l}\text { Belum dapat membuat konjektur dari } \\
\text { suatu pola bilangan }\end{array}$ \\
3. & $\begin{array}{l}\text { Penyelesaian masalah yang melibatkan } \\
\text { ekspresi matematis belum sistematis }\end{array}$ \\
\hline
\end{tabular}


DOI: https://doi.org/10.24127/ajpm.v9i2.2695

Berdasarkan hasil pekerjaan tertulis dan wawancara dari subjek FDIL dalam representasi simbolik menunjukkan ciri-ciri seperti pada Tabel 2.

\section{Representasi Verbal}

Subjek FDIL belum mampu membuat situasi masalah berdasarkan data atau representasi yang diketahui. FDIL dapat menuliskan interprestasi dari suatu representasi. Dalam menyelesaikan masalah, FDIL belum dapat menyusun prosedur penyelesaian masalah yang disertai dengan penjelasan. Subjek FDIL hanya menuliskan rumus dan menjawab soal secara mekanik. Gambar 3 adalah contoh hasil pekerjaan subjek FDIL dalam merepresentasikan matematis secara verbal.

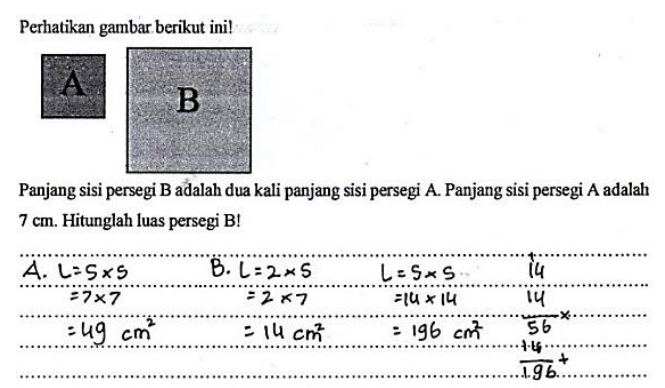

Gambar 3. Hasil pekerjaan subjek FDIL dalam representasi verbal.

Pada saat wawancara dengan FDIL, subjek tersebut belum dapat membuat suatu pertanyaan atau situasi masalah berdasarkan representasi yang diketahui. Namun, ketika diminta untuk menginterprestasikan suatu representasi, subjek dapat melakukannya dengan tepat. Subjek FDIL belum dapat menyusun kata-kata yang tepat untuk menjelaskan langkah-langkah penyelesaian masalah matematis. Subjek FDIL hanya mampu menuliskan rumus dan menjawab soal secara tertulis.
Berdasarkan hasil pekerjaan tertulis dan wawancara dari subjek FDIL dalam representasi verbal menunjukkan ciri-ciri seperti pada Tabel 3.

Tabel 3. Representasi verbal subjek FDIL.

\begin{tabular}{cl}
\hline No & \multicolumn{1}{c}{ Keterangan } \\
\hline 1. & $\begin{array}{l}\text { Belum mampu membuat situasi masalah } \\
\text { berdasarkan data atau representasi yang } \\
\text { diketahui }\end{array}$ \\
2. & $\begin{array}{l}\text { Mampu menuliskan interprestasi dari } \\
\text { suatu representasi } \\
\text { Belum mampu menyusun langkah- } \\
\text { langkah penyelesaian masalah matematis } \\
\text { dengan kata-kata dengan }\end{array}$ \\
4. & $\begin{array}{l}\text { Dapat menjawab soal denganan teks tertulis } \\
\text { menggunakan }\end{array}$
\end{tabular}

Secara lengkap profil representasi matematis subjek FDIL disajikan pada Tabel 4.

\section{Profil Kemampuan Representasi Matematis Siswa FDIS \\ Subjek Field Intermediate Sedang} (FDIS) adalah subjek FDI yang masuk kategori sedang, yaitu skor GEFT yang diperoleh adalah 11. Berikut ini adalah penjelasan lebih rinci dari kemampuan representasi matematis subjek FDIS dalam menyelesaikan soal etnomatematika.

1. Representasi Visual

Subjek FDIS belum dapat menyajikan kembali data atau informasi dari suatu representasi ke dalam bentuk tabel. FDIS dapat memanfaatkan representasi visual untuk menyelesaikan masalah secara sistematis. Dalam membuat gambar pola-pola geometri, subjek FDIS hanya dapat membuat satu gambar lengkap dengan informasi gambar tersebut. Siswa dapat membuat gambar bangun geometri berdasarkan permasalahan kemudian gambar tersebut digunakan sebagai media untuk mempermudah dalam melakukan penyelesaian. 
DOI: https://doi.org/10.24127/ajpm.v9i2.2695

Tabel 4. Profil representasi matematis subjek FDIL.

\begin{tabular}{|c|c|c|}
\hline No & Aspek & Indikator \\
\hline 1. & $\begin{array}{l}\text { Representasi } \\
\text { visual }\end{array}$ & $\begin{array}{l}\text { a. Belum mampu menyajikan ulang data dari suatu representasi ke representasi } \\
\text { tabel. } \\
\text { b. Mampu memanfaatkan representasi visual untuk memecahkan masalah tetapi } \\
\text { belum dapat menyusun proses penyelesaiannya secara sistematis. } \\
\text { c. Dapat membuat satu gambar pola geometri. } \\
\text { d. Dapat menggambar bangun geometri untuk membantu memvisualisasikan } \\
\text { permasalahan dan untuk memfasilitasi pemecahan masalah. }\end{array}$ \\
\hline 2. & $\begin{array}{l}\text { Representasi } \\
\text { simbolik }\end{array}$ & $\begin{array}{l}\text { a. Dapat menyusun persamaan atau model matematika dari representasi lain yang } \\
\text { diketahui. } \\
\text { b. Belum dapat membuat konjektur dari suatu pola bilangan. } \\
\text { c. Penyelesaian masalah yang melibatkan ekspresi matematis belum sistematis. }\end{array}$ \\
\hline 3. & $\begin{array}{l}\text { Representasi } \\
\text { verbal }\end{array}$ & $\begin{array}{l}\text { a. Belum mampu membuat situasi masalah berdasarkan data atau representasi yang } \\
\text { diketahui. } \\
\text { b. Mampu menuliskan interprestasi dari suatu representasi. } \\
\text { c. Belum mampu menyusun langkah-langkah penyelesaian masalah matematis } \\
\text { dengan kata-kata. } \\
\text { d. Dapat menjawab soal dengan menggunakan teks tertulis. }\end{array}$ \\
\hline
\end{tabular}

Gambar 4 adalah contoh hasil pekerjaan subjek FDIS dalam merepresentasikan matematis secara visual.

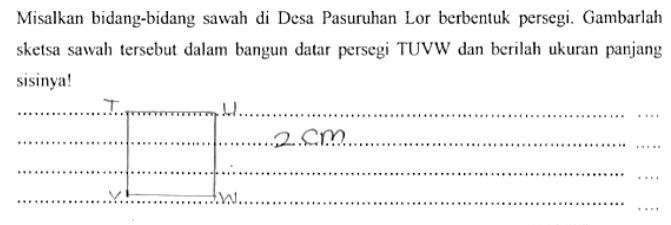

Gambar 4. Hasil pekerjaan subjek FDIS dalam representasi visual.

Pada saat wawancara dilakukan, subjek FDIS dapat menyelesaikan masalah tetapi belum mampu menyajikan hasilnya ke dalam bentuk representasi tabel. FDIS merasa terbantu dengan adanya visualisasi permasalahan di dalam soal. Dalam penyelesaian masalah, FDIS dapat menyusun proses penyelesaiannya secara sistematis. Subjek FDIS hanya membuat satu gambar ketika diminta untuk membuat pola-pola geometri, tetapi sudah lengkap dengan keterangan gambarnya. FDIS dapat menggambar bangun geometri berdasarkan permasalahan kemudian gambar tersebut untuk memfasilitasi dirinya untuk menyelesaikan masalah.

Berdasarkan hasil pekerjaan tertulis dan wawancara dari subjek FDIS dalam representasi visual menunjukkan ciri-ciri seperti pada Tabel 5.

Tabel 5. Representasi Visual Subjek FDIS

\begin{tabular}{cl}
\hline No & \multicolumn{1}{c}{ Keterangan } \\
\hline 1. & $\begin{array}{l}\text { Belum mampu menyajikan ulang data dari } \\
\text { suatu representasi ke representasi tabel }\end{array}$ \\
2. & $\begin{array}{l}\text { Mampu memanfaatkan representasi visual } \\
\text { untuk memecahkan masalah secara }\end{array}$ \\
sistematis & $\begin{array}{l}\text { Dapat menggambar satu pola geometri } \\
\text { lengkap dengan informasi gambar tersebut }\end{array}$ \\
4. & $\begin{array}{l}\text { Dapat menggambar bangun geometri } \\
\text { untuk membantu memvisualisasikan } \\
\text { permasalahan dan untuk memfasilitasi } \\
\text { pemecahan masalah }\end{array}$ \\
\hline
\end{tabular}

2. Representasi Simbolik

Subjek FDIS dapat menyusun persamaan atau model matematika dari suatu representasi verbal yang diketahui. FDIS belum dapat membuat konjektur dari suatu pola bilangan. Dalam melakukan penyelesaian masalah dengan melibatkan ekspresi 
matematis, subjek FDIS dapat menyusun secara sistematis tetapi masih kurang tepat dalam memberikan satuan. Gambar 5 adalah contoh hasil pekerjaan subjek FDIS dalam merepresentasikan matematis secara simbolik.

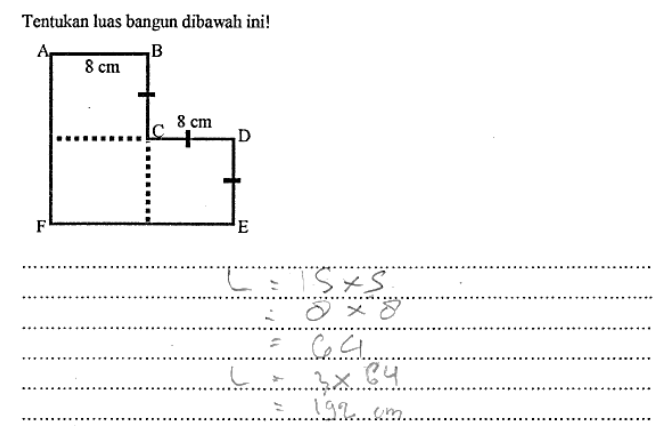

Gambar 5. Hasil pekerjaan subjek FDIS dalam representasi simbolik.

Pada saat wawancara dilakukan, subjek FDIS dapat menyusun persamaan atau model matematika dari representasi verbal yang diketahui. FDIS belum dapat membuat konjektur dari suatu pola bilangan. Subjek FDIS mampu menyusun penyelesaian dengan melibatkan ekspresi matematis secara sistematis, tetapi masih kurang tepat dalam memberikan satuan.

Berdasarkan hasil pekerjaan tertulis dan wawancara dari subjek FDIS dalam representasi simbolik menunjukkan ciri-ciri seperti pada Tabel 6.

Tabel 6. Representasi simbolik subjek FDIS

\begin{tabular}{cl}
\hline No & \multicolumn{3}{c}{ Keterangan } \\
\hline 1. & $\begin{array}{l}\text { Dapat membuat persamaan atau model } \\
\text { matematis dari representasi lain yang } \\
\text { diberikan }\end{array}$ \\
2. & $\begin{array}{l}\text { Belum dapat membuat konjektur dari } \\
\text { suatu pola bilangan }\end{array}$ \\
3. & $\begin{array}{l}\text { Penyelesaian masalah dengan melibatkan } \\
\text { ekspresi matematis dilakukan secara }\end{array}$ \\
sistematis, tetapi masih kurang tepat \\
dalam memberikan satuan
\end{tabular}

\section{Representasi Verbal}

Subjek FDIS belum dapat membuat situasi masalah berdasarkan data atau representasi yang diketahui. FDIS dapat menuliskan interprestasi dari suatu representasi. Dalam menyelesaikan masalah, FDIS belum dapat menyusun kata-kata untuk menuliskan langkah-langkah penyelesaian masalah matematis. Subjek FDIS hanya menuliskan penyelesaian dari permasalahan yang diberikan. Gambar 6 adalah contoh hasil pekerjaan subjek FDIS dalam merepresentasikan matematis secara verbal.

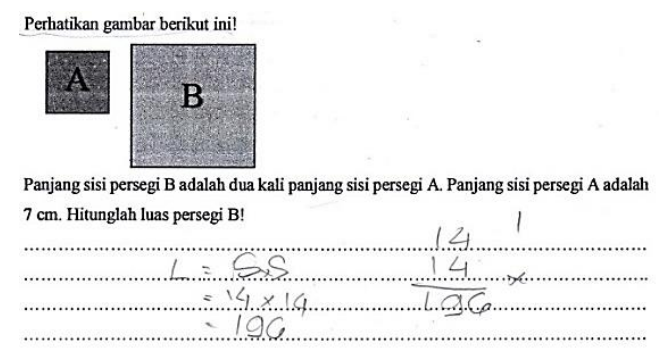

Gambar 6. Hasil pekerjaan subjek FDIS dalam representasi verbal.

Tabel 7. Representasi verbal subjek FDIS.

\begin{tabular}{cl}
\hline No & \multicolumn{1}{c}{ Keterangan } \\
\hline 1. & $\begin{array}{l}\text { Belum mampu membuat situasi masalah } \\
\text { berdasarkan data atau representasi yang } \\
\text { diketahui }\end{array}$ \\
2. & $\begin{array}{l}\text { Mampu menuliskan interprestasi dari } \\
\text { suatu representasi }\end{array}$ \\
3. $\begin{array}{l}\text { Belum dapat menyusun kata-kata untuk } \\
\text { menuliskan langkah-langkah penyelesaian } \\
\text { masalah matematis }\end{array}$ \\
4. $\begin{array}{l}\text { Dapat menjawab soal dengan } \\
\text { menggunakan teks tertulis, tanpa } \\
\text { memberikan keterangan apa yang sedang } \\
\text { dicari penyelesaiannya. }\end{array}$ \\
Pada saat wawancara dengan
\end{tabular}
FDIS, subjek tersebut belum dapat membuat suatu pertanyaan atau situasi masalah berdasarkan representasi yang diketahui. Namun, ketika diminta untuk menginterprestasikan suatu representasi, subjek dapat melakukannya dengan 
DOI: https://doi.org/10.24127/ajpm.v9i2.2695

tepat. Subjek FDIS belum dapat menyusun kata-kata untuk menuliskan langkah-langkah penyelesaian masalah matematis. Subjek FDIS telah memahami permasalahan dan proses penyelesaian masalah dengan tepat, tetapi subjek hanya mampu menuliskan jawaban dari penyelesaian masalah dengan tidak menyertakan pengantar.
Berdasarkan hasil pekerjaan tertulis dan wawancara dari subjek FDIS dalam representasi verbal menunjukkan ciri-ciri seperti pada Tabel 7.

Secara lengkap profil representasi matematis subjek FDIS disajikan pada Tabel 8.

Tabel 8. Profil representasi matematis subjek FDIS.

\begin{tabular}{|c|c|c|}
\hline No & Aspek & Indikator \\
\hline 1. & $\begin{array}{l}\text { Representasi } \\
\text { visual }\end{array}$ & $\begin{array}{l}\text { a. Belum mampu menyajikan ulang data dari suatu representasi ke representasi } \\
\text { tabel. } \\
\text { b. Mampu memanfaatkan representasi visual untuk memecahkan masalah secara } \\
\text { sistematis. } \\
\text { c. Dapat menggambar satu pola geometri lengkap dengan informasi gambar } \\
\text { tersebut. } \\
\text { d. Dapat menggambar bangun geometri untuk membantu memvisualisasikan } \\
\text { permasalahan dan untuk memfasilitasi pemecahan masalah. }\end{array}$ \\
\hline 2. & $\begin{array}{l}\text { Representasi } \\
\text { simbolik }\end{array}$ & $\begin{array}{l}\text { a. Dapat membuat persamaan atau model matematis dari representasi lain yang } \\
\text { diberikan. } \\
\text { b. Belum dapat membuat konjektur dari suatu pola bilangan. } \\
\text { c. Penyelesaian masalah dengan melibatkan ekspresi matematis dilakukan secara } \\
\text { sistematis, tetapi masih kurang tepat dalam memberikan satuan. }\end{array}$ \\
\hline 3. & $\begin{array}{l}\text { Representasi } \\
\text { verbal }\end{array}$ & $\begin{array}{l}\text { a. Belum mampu membuat situasi masalah berdasarkan data atau representasi yang } \\
\text { diketahui. } \\
\text { b. Mampu menuliskan interprestasi dari suatu representasi. } \\
\text { c. Belum dapat menyusun kata-kata untuk menuliskan langkah-langkah } \\
\text { penyelesaian masalah matematis. } \\
\text { d. Dapat menjawab soal dengan menggunakan teks tertulis, tanpa memberikan } \\
\text { keterangan apa yang sedang dicari penyelesaiannya. }\end{array}$ \\
\hline
\end{tabular}

\section{Profil Kemampuan Representasi Matematis Siswa FDIK}

Subjek Field Intermediate Kuat (FDIK) adalah subjek FDI yang memiliki skor GEFT tertinggi dalam kategori FDI. Skor GEFT yang diperoleh subjek FDIK adalah 12. Berikut ini adalah penjelasan lebih rinci dari kemampuan representasi matematis subjek FDIK dalam menyelesaikan soal etnomatematika.

\section{Representasi Visual}

Subjek FDIK belum dapat menyajikan kembali data atau informasi dari suatu representasi ke dalam bentuk tabel. FDIK dapat memanfaatkan representasi visual untuk menyelesaikan masalah secara sistematis. Dalam membuat gambar pola-pola geometri, subjek FDIK hanya dapat membuat satu gambar lengkap dengan keterangan gambarnya. Siswa dapat membuat gambar bangun geometri berdasarkan permasalahan tetapi tidak digunakan untuk memfasilitasi penyelesaian. Gambar 7 adalah contoh hasil pekerjaan subjek FDIK dalam merepresentasikan matematis secara visual.

Pada saat wawancara dilakukan, subjek FDIK belum dapat menyajikan hasil penyelesaian masalahnya ke dalam bentuk tabel. FDIK memanfaatkan representasi visual untuk menyelesaikan masalah secara sistematis. Subjek 
merasa lebih mudah dalam menyelesaikan masalah dengan adanya visualisasi permasalahan di dalam soal. Subjek FDIK hanya membuat satu gambar lengkap dengan keterangan gambarnya ketika diminta untuk membuat pola-pola geometri. FDIK dapat menggambar bangun geometri berdasarkan permasalahan tetapi gambar tersebut tidak digunakan untuk memfasilitasi penyelesaian.

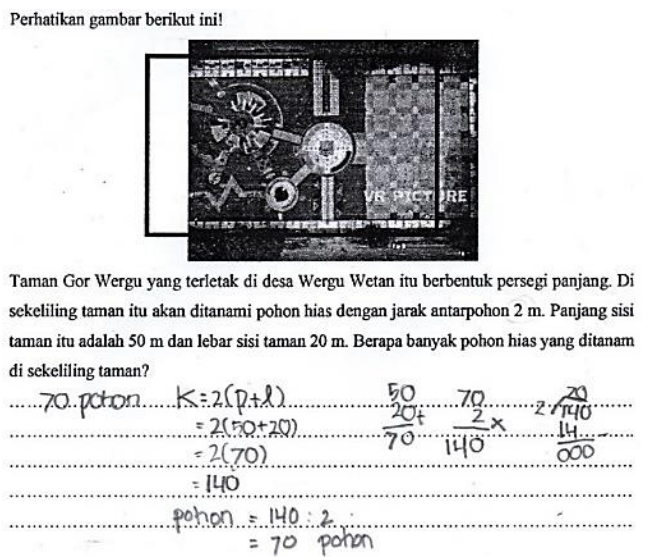

Gambar 7. Hasil pekerjaan subjek FDIK dalam representasi visual.

Berdasarkan hasil pekerjaan tertulis dan wawancara dari subjek FDIK dalam representasi visual menunjukkan ciri-ciri seperti pada Tabel 9.

Tabel 9. Representasi visual subjek FDIK.

\begin{tabular}{|c|c|}
\hline No & Keterangan \\
\hline 1. & $\begin{array}{l}\text { Belum mampu menyajikan ulang data dari } \\
\text { suatu representasi ke representasi tabel }\end{array}$ \\
\hline 2. & $\begin{array}{l}\text { Mampu memanfaatkan representasi visual } \\
\text { untuk memecahkan masalah secara } \\
\text { sistematis }\end{array}$ \\
\hline 3. & $\begin{array}{l}\text { Mampu menggambar satu pola geometri } \\
\text { lengkap dengan keterangan gambar }\end{array}$ \\
\hline 4. & $\begin{array}{lll}\text { Dapat menggambar bangun geometri } \\
\text { untuk membantu memvisualisasikan } \\
\text { permasalahan tetapi tidak untuk } \\
\text { memfasilitasi pemecahan masalah }\end{array}$ \\
\hline
\end{tabular}

2. Representasi Simbolik
Subjek FDIK dapat menyusun persamaan atau model matematika dari suatu representasi verbal yang diketahui. FDIK belum dapat membuat konjektur dari suatu pola bilangan. Dalam melakukan pemecahan masalah dengan melibatkan ekspresi matematis, subjek FDIK belum dapat menyusun secara sistematis. Gambar 8 adalah contoh hasil pekerjaan subjek FDIK dalam merepresentasikan matematis secara simbolik.

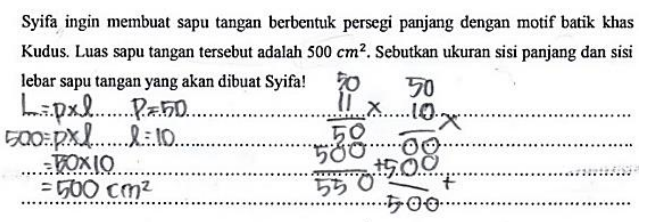

Gambar 8. Hasil Pekerjaan Subjek FDIK dalam Representasi Simbolik

Pada saat wawancara dilakukan, subjek FDIK dapat menyusun persamaan atau model matematika dari representasi verbal yang diketahui. FDIK belum dapat membuat konjektur dari suatu pola bilangan. FDIK berusaha mencoba menyelesaikan permasalahan berkaitan dengan membuat konjektur dari suatu pola bilangan tetapi berhenti di tengah penyelesaian. Subjek FDIK belum dapat menyusun penyelesaian masalah yang melibatkan ekspresi matematis secara sistematis.

Tabel 10. Representasi simbolik subjek FDIK.

\begin{tabular}{cl}
\hline No & \multicolumn{1}{c}{ Keterangan } \\
\hline 1. & $\begin{array}{l}\text { Dapat menyusun persamaan atau model } \\
\text { matematika dari representasi lain yang } \\
\text { diketahui }\end{array}$ \\
2. & $\begin{array}{l}\text { Belum dapat membuat konjektur dari } \\
\text { suatu pola bilangan }\end{array}$ \\
3. & $\begin{array}{l}\text { Penyelesaian masalah yang melibatkan } \\
\text { ekspresi matematis belum sistematis }\end{array}$ \\
\hline
\end{tabular}


Dari data pekerjaan tertulis dan wawancara dari subjek FDIK dalam representasi simbolik menunjukkan ciriciri seperti pada Tabel 10.

\section{Representasi Verbal}

Subjek FDIK belum mampu membuat situasi masalah berdasarkan representasi yang diketahui. FDIK mampu menuliskan interprestasi dari suatu representasi. Dalam menyelesaikan masalah, FDIK belum dapat menyusun prosedur penyelesaian masalah yang disertai dengan penjelasan. Subjek FDIK hanya menuliskan rumus dan menjawab soal secara mekanik. Gambar 9 adalah contoh hasil pekerjaan subjek FDIK dalam merepresentasikan matematis secara verbal.

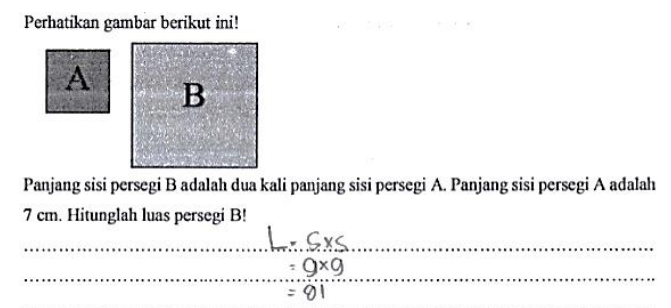

Gambar 9. Hasil pekerjaan subjek FDIK dalam representasi verbal.

Pada saat wawancara dengan FDIK, subjek tersebut belum dapat membuat suatu pertanyaan atau situasi masalah berdasarkan representasi yang diketahui. Namun, ketika diminta untuk menginterprestasikan suatu representasi, subjek dapat melakukannya dengan tepat. Subjek FDIK belum dapat menyusun kata-kata untuk menjelaskan langkah-langkah penyelesaian masalah matematis. Subjek FDIK hanya mampu menuliskan rumus dan menjawab soal secara tertulis.

Berdasarkan hasil pekerjaan tertulis dan wawancara dari subjek FDIK dalam representasi verbal menunjukkan ciri-ciri seperti pada Tabel 11.

Tabel 11. Representasi verbal subjek FDIK.

\begin{tabular}{cl}
\hline No & \multicolumn{1}{c}{ Keterangan } \\
\hline 1. & $\begin{array}{l}\text { Belum mampu membuat situasi masalah } \\
\text { berdasarkan data atau representasi yang } \\
\text { diketahui }\end{array}$ \\
2. & $\begin{array}{l}\text { Mampu menuliskan interprestasi dari } \\
\text { suatu representasi }\end{array}$ \\
3. Belum mampu menyusun prosedur \\
penyelesaian masalah dengan penjelasan \\
4. \\
menpu menjawab soal dengan \\
\hline
\end{tabular}

Secara lengkap profil representasi matematis subjek FDIK disajikan pada Tabel 12.

Penelitian ini dilakukan di SD 1 Muhammadiyah Kudus. Penelitian dilaksanakan di kelas III pada semester genap tahun pelajaran 2017/2018. Subjek penelitian adalah siswa kelas III yang memiliki gaya kognitif FDI. Penetapan subjek dalam penelitian ini berpedoman pada hasil tes gaya kognitif. Subjek dipilih dengan melihat skor hasil tes GEFT. Berdasarkan hasil tes GEFT dikelompokkan menjadi 3, yaitu siswa FDIL (rendah), FDIS (sedang), FDIK (tinggi). Profil kemampuan representasi matematis ditinjau dari representasi visual, simbolik, dan verbal siswa pada setiap kategori berbeda-beda. Setiap siswa memiliki kemampuan representasi yang berbeda-beda sehingga teknik siswa dalam menerima, memahami, dan menganalisis informasi yang diperoleh juga berbeda (Syahid \& Noviartati, 2019). Perbedaan ini yang disebut gaya kognitif.

Subjek FDIL sudah mempunyai kemampuan representasi visual berupa pembuatan gambar pola geometri untuk memperjelas masalah, akan tetapi masih belum dapat menyajikan algoritma 
penyelesaian masalah secara sistematik. Subjek FDIL memiliki skor GEFT yang mendekati FD sehingga subjek FDIL memiliki kecenderungan yang sama dengan subjek FD. Siswa FD menyampaikan hal yang diketahui dan ditanyakan menggunakan representasi visual secara perlahan-lahan dan benar kemudian menyampaikannya dalam bentuk gambar untuk mempermudah pengerjaannya, akan tetapi dalam memahaminya siswa terlihat kurang fokus (Tyas, Sujadi, \& Riyadi, 2016). Pada soal etnomatematika, terdapat soal yang mengharuskan siswa untuk membuat gambar geometri dari situasi yang diberikan. Siswa dapat membuat gambar karena soal yang diberikan didekatkan dengan kebudayaan yang ada di sekitar siswa. Kesalahan siswa dalam menyusun prosedur penyelesaian masalah terjadi karena siswa tidak menuliskan secara sistematis langkahlangkah pengerjaan soal dan kesalahan algoritma (Wati \& Sujadi, A., 2017). Subjek FDIL juga masih mengalami kesulitan menyajikan informasi dalam bentuk tabel. Kesulitan siswa dalam membuat tabel disebabkan karena rendahnya pemahaman konsep siswa dalam membuat tabel distribusi frekuensi (Saiman, 2016).

Tabel 12. Profil representasi matematis subjek FDIK.

\begin{tabular}{|c|c|c|}
\hline No & Aspek & Indikator \\
\hline 1. & $\begin{array}{l}\text { Representasi } \\
\text { visual }\end{array}$ & $\begin{array}{l}\text { a. Belum mampu menyajikan ulang data dari suatu representasi ke representasi } \\
\text { tabel. } \\
\text { b. Mampu memanfaatkan representasi visual untuk memecahkan permasalahan } \\
\text { secara sistematis. } \\
\text { c. Mampu menggambar satu pola geometri lengkap dengan keterangan gambar. } \\
\text { d. Dapat menggambar bangun geometri untuk membantu memvisualisasikan } \\
\text { permasalahan tetapi tidak untuk memfasilitasi pemecahan masalah. }\end{array}$ \\
\hline 2. & $\begin{array}{l}\text { Representasi } \\
\text { simbolik }\end{array}$ & $\begin{array}{l}\text { a. Dapat menyusun persamaan atau model matematika dari representasi lain yang } \\
\text { diketahui. } \\
\text { b. Belum dapat membuat konjektur dari suatu pola bilangan. } \\
\text { c. Penyelesaian masalah yang melibatkan ekspresi matematis belum sistematis. }\end{array}$ \\
\hline 3. & $\begin{array}{l}\text { Representasi } \\
\text { verbal }\end{array}$ & $\begin{array}{l}\text { a. Belum mampu membuat situasi masalah berdasarkan data atau representasi } \\
\text { yang diketahui. } \\
\text { b. Mampu menuliskan interprestasi dari suatu representasi. } \\
\text { c. Belum mampu menyusun prosedur penyelesaian masalah dengan penjelasan. } \\
\text { d. Mampu menjawab soal dengan menggunakan teks tertulis. }\end{array}$ \\
\hline
\end{tabular}

Pada aspek representasi simbolik, subjek FDIL sudah mempunyai kemampuan menyusun persamaan atau model matematika dari suatu representasi yang diketahui. Subjek FDIL sudah mampu membuat model matematis dikarenakan pembelajaran etnomatematika mengakomodasi siswa untuk lebih mudah memahami soal cerita. Namun, subjek FDIL belum dapat membuat konjektur dari suatu pola bilangan dan melibatkan ekspresi matematis belum sistematis untuk menyelesaikan masalah. Kesalahan siswa dalam menjawab dikarenakan siswa masih mengalami kesulitan memahami dan membedakan penggunaan simbol dan lambang matematika (Ruhyana, 2016).

Kemampuan representasi verbal subjek FDIL yang sudah tercapai yaitu siswa dapat menuliskan interprestasi dari suatu representasi dan dapat menjawab soal dengan menggunakan teks tertulis. Sedangkan representasi verbal yang masih rendah yaitu pembuatan situasi masalah berdasarkan data atau representasi yang diberikan 
dan menyusun langkah-langkah penyelesaian masalah matematis dengan kata-kata. Ketidakmampuan siswa dalam penyusunan situasi masalah ini dikarenakan siswa tidak memahami makna soal (Wati \& Sujadi, A., 2017).

Profil kemampuan representasi visual subjek FDIS menunjukkan hasil yang lebih baik daripada siswa FDIL. Representasi visual dari subjek FDIS yang sudah berkembang yaitu kemampuan menggunakan representasi visual untuk menyelesaikan masalah secara sistematis. Subjek FDIS juga sudah mampu membuat satu gambar geometri lengkap dengan informasi dari gambar tersebut. Subjek FDIS mengalami kesulitan dalam menyajikan representasi visual dalam bentuk tabel.

Sama halnya dengan subjek FDIL, kemampuan representasi simbolik dari subjek FDIS dapat menyusun persamaan atau model matematika dari suatu representasi verbal yang diketahui. FDIS juga belum dapat membuat konjektur dari suatu pola bilangan. Subjek FDIS menunjukkan kemampuan yang lebih baik dalam melakukan penyelesaian masalah yang melibatkan ekpresi matematis meskipun kurang tepat dalam memberikan satuan pada jawaban. Dengan penggunaan etnomatematika pada soal, mempengaruhi kemampuan siswa dalam menafsirkan makna simbol dan menerapkannya dalam penyelesaian soal (Sarwoedi, Marinka, Febriani, \& Wirne, 2018).

Representasi verbal subjek FDIS yang sudah tercapai yaitu kemampuan menuliskan interprestasi dari suatu representasi dan menyelesaikan soal dengan menggunakan teks tertulis tetapi tidak menuliskan apa yang ditanyakan oleh soal. Subjek FDIS masih belum mampu membuat situasi masalah berdasarkan representasi yang diketahui dan masih mengalami kesulitan mengemukakan langkah penyelesaian matematis dengan menggunakan katakata. Siswa yang mengalami kesulitan dalam memahami soal tidak dapat menuliskan masalah yang berakibat pada terhambatnya penyelesaian masalah (Wati \& Sujadi, A., 2017).

Subjek FDIK adalah subjek dengan skor GEFT tertinggi dalam kategori FDI. Artinya subjek ini memiliki skor yang mendekati siswa dengan gaya kognitif FI. Ketika disajikan gambar di soal etnomatematika, subjek FDIK dapat memanfaatkan representasi visual untuk menyelesaikan masalah secara sistematis. Dengan adanya visualisasi permasalahan, subjek FDIK lebih mudah menjawab pertanyaan. Untuk soal cerita tanpa gambar, subjek FDIK dapat membuat gambar bangun geometri berdasarkan permasalahan tetapi tidak digunakan untuk memfasilitasi penyelesaian. Dalam menggambar pola-pola geometri, subjek FDIK hanya mampu membuat satu gambar lengkap dengan keterangan gambarnya. Meskipun subjek FDIK memiliki skor yang mendekati FI, akan tetapi memiliki kemampuan yang berbeda. Individu FI mampu menganalisis dan mengisolasi rincian yang relevan, mendeteksi pola, dan mengevaluasi secara kritis suatu persoalan (Yousefi, 2011). Subjek FDIK belum dapat menyajikan kembali data atau informasi dari suatu representasi ke dalam bentuk tabel. Kelemahan ini sama halnya dengan subjek FDIL dan FDIS.

Subjek FDIK dapat menyusun persamaan atau model matematika dari representasi lain. FDIK belum dapat membuat konjektur dari suatu pola bilangan. FDIK berusaha mencoba menyelesaikan permasalahan berkaitan 
dengan membuat konjektur dari suatu pola bilangan tetapi berhenti di tengah penyelesaian. Subjek FDIK memerlukan motivasi eksternal untuk meyelesaikan masalah. Subjek FDIK belum dapat menyusun penyelesaian masalah dengan melibatkan ekspresi matematis secara sistematis. Pada aspek representasi simbolik, secara keseluruhan siswa FDI belum mampu membuat konjektur dari suatu pola bilangan.

Pada aspek representasi verbal, subjek FDIK masih mengalami hambatan, yaitu belum mampu membuat situasi masalah berdasarkan representasi yang diketahui. Subjek FDIK hanya menuliskan rumus dan menjawab soal secara mekanik tetapi tidak dapat mengekpresikan solusi penyelesaian masalah dengan menggunakan kata-kata. Kecenderungan subjek FDIK seperti siswa dengan gaya kognitif FI yang individual menyebabkan kemampuan representasi baik tetapi ada beberapa aspek yang masih lemah (Ulya et al., 2014).

Gaya kognitif mempengaruhi proses berpikir siswa dalam belajar matematika, sehingga mempengaruhi pula dalam proses pemecahan masalah siswa. Guru harus membantu mengupayakan untuk tercapainya kemampuan tersebut. Guru dapat menggunakan berbagai cara untuk menganalisis tingkat kemampuan representasi matematis siswa. Guru dapat mengembangkan suatu alat ukur atau instrumen untuk menganalisis, mengukur, atau mengidentifikasi kemampuan representasi matematis siswa. Selain itu, guru perlu memperhatikan kondisi tersebut dalam kegiatan pembelajaran di kelas. Perhatian guru terhadap perbedaan gaya kognitif siswa tentunya akan berimplikasi pada pemilihan strategi pembelajaran yang sesuai sehingga dapat memberikan hasil belajar yang positif bagi siswa dengan berbagai gaya kognitif. Kurangnya ketertarikan siswa terhadap matematika berpengaruh pada kemampuan siswa dalam pemecahan masalah matematika. Guru dapat menciptakan susasana belajar yang nyaman dan sistem pembelajaran disesuaikan dengan gaya kognitif siswa.

\section{KESIMPULAN DAN SARAN}

Kesimpulan penelitian ini yaitu profil representasi matematis siswa FDI tergolong baik, tetapi masih banyak kendala yang dihadapi. dalam representasi visual, siswa belum dapat menyajikan kembali data atau informasi dari suatu representasi ke representasi tabel; dalam representasi simbolik, siswa belum dapat membuat konjektur dari suatu pola bilangan; dan dalam representasi verbal, siswa belum dapat membuat situasi masalah berdasarkan data atau representasi yang diberikan, dan belum dapat menyusun langkahlangkah penyelesaian masalah matematis dengan kata-kata.

Saran dalam penelitian ini yaitu siswa dapat lebih dibiasakan untuk menyelesaikan masalah secara sistematis agar siswa terbiasa dengan pola berpikir yang baik dalam menyelesaikan masalah. Selain itu untuk penelitian selanjutnya, soal etnomatematika dapat digunakan untuk mengukur kemampuan matematis yang lain.

\section{DAFTAR PUSTAKA}

Akramunnisa, Tahmir, S., \& Dassa, A. (2017). Ability Analysis Based on Math Problem Completing The Early Math Skills And Cognitive Style on Class VIII SMPN 13 Makassar. Jurnal Daya Matematis, 5(1), 14-26. 
Arisetyawan, A., Suryadi, D., Herman, T., \& Rahmat, C. (2014). Study of Ethnomathematics: A Lesson From The Baduy Culture. Journal of Education and Research, 2(10), 681-688.

Azizah, L. N., Junaidi, I., \& S. (2019). Kemampuan Representasi Matematis Ditinjau dari Gaya Kognitif Siswa Kelas X pada Pembelajaran Matematika dengan Model Problem Based Learning. PRISMA, Prosiding Seminar Nasional Matematika 2, 355-365.

Brown, E., Brailsford, T., Fisher, T., Moore, A., \& Ashman, H. (2006). Reappraising Cognitive Styles in Adaptive Web Applications. Proceedings of the 15th International World Wide Web Conference (WWW'06), 327-335. https://doi.org/10.1145/1135777.11 35827

Effendi, L. A. (2012). Pembelajaran Matematika dengan Metode Penemuan Terbimbing untuk Meningkatkan Kemampuan Representasi dan Pemecahan Masalah Matematis Siswa SMP. Jurnal Pendidikan Indonesia, 13(2), 1-10.

Handayani, H., \& Juanda, R. (2018). Profil Kemampuan Representasi Matematis Siswa Sekolah Dasar Di Kecamatan Sumedang Selatan. Prosiding Seminar Nasional Matematika Dan Pendidikan Matematika (Sesiomadika), 443448.

Hendriana, H. (2012). Pembelajaran Matematika Humanis dengan Metaphorical Thinking Untuk Meningkatkan Kepercayaan Diri Siswa. Jurnal Iinfinity, 1(1), 90103.

Kozhevnikov, M. (2007). Cognitive Styles in the Context of Modern
Psychology: Toward an Integrated Framework of Cognitive Style. Psychological Bulletin, 133(3), 464-481.

https://doi.org/10.1037/00332909.133.3.464

Mahardiyanti, T. (2014). Penerapan Metode Pembelajaran Problem Based Learning (PBL) Untuk Meningkatkan Kemampuan Representasi Matematis Siswa Kelas V SDN Bader 01 Tahun Pelajaran 2014/2015. Jurnal Ilmiah Pendidikan, 2(2), 142-149.

Manurung, O., \& Kartono. (2016). Keterampilan Penalaran Induktif Deduktif dan Kemampuan Representasi Matematis Siswa Pada Pembelajaran CTL Berbasis Hands On Activity. Unnes Journal of Mathematics Education Research, 5(2), 155-165.

Minarni, A., Napitupulu, E. E., \& Husein, R. (2016). Mathematical Understanding and Representation Ability of Public Junior High School in North Sumatra. Journal on Mathematics Education, 7(1), 43-56.

Mullis, I. V. S., Martin, M. O., Foy, P., \& Hooper, M. (2015). TIMSS 2015 International Results in Mathematics. Chestnut Hill, MA: TIMSS \& PIRLS International Study Center, Boston College.

Ngilawajan, D. A. (2013). Proses Berpikir Siswa SMA dalam Memecahkan Masalah Matematika Materi Turunan Ditinjau dari Gaya Kognitif Field Independent dan Field Dependent. Jurnal Pedagogia, 2(1), 71-83.

OECD. (2019). PISA 2018 Results.

Permata, J. I., Sukestiyarno, Y. L., \& Hindarto, N. (2017). Analisis Representasi Matematis Ditinjau dari Kreativitas Pembelajaran CPS 
DOI: https://doi.org/10.24127/ajpm.v9i2.2695

dengan Asesmen Diagnostik. Unnes Journal of Mathematics Education Research, 6(2), 233241.

Ruhyana. (2016). Analisis Kesulitan Siswa dalam Pemecahan Masalah Matematika. Jurnal Computech \& Bisnis, 10(2), 106-118.

Saiman. (2016). Analisis Kesulitan Siswa dalam belajar Statistik Khususnya pada Histogram. AKSIOMA Jurnal Pendidikan Matematika, 5(2), 231-240.

Sari, Y. M., Juniati, D., \& Lukito, A. (2014). Profil Penalaran Siswa SD dalam Membuktikan Konservasi Luas Bangun Datar Ditinjau Dari Gaya Kognitif Field Independent dan Field Dependent. Jurnal Dikma, 2(4), 29-32.

Sarwoedi, Marinka, D. O., Febriani, P., \& Wirne, I. N. (2018). Efektivitas Etnomatematika dalam Meningkatkan Kemampuan Pemahaman Matematika Siswa. Jurnal Pendidikan Matematika Raflesia, 3(2), 171-176.

Siswono, T. Y. E. (2012). Implementasi Pendidikan Karakter dalam Pembelajaran Matematika. Prosiding SNPM UIN Syarif Hidayatullah Jakarta:, 1-12.

Syahid, M., \& Noviartati. (2019). Representasi Matematis Siswa Bergaya Kognitif VisualizerVerbalizer dalam Menyelesaikan Soal Matematika TIMSS. Jurnal Gantang, 4(1), 49-59.
Tyas, W. H., Sujadi, I., \& Riyadi. (2016). Representasi Matematis Siswadalammenyelesaikan Masalah Matematikapada Materi Aritmatika Sosial dan Perbandingan ditinjau dari Gaya Kognitif Siswa Kelas VII SMP Negeri 15 Surakarta Tahun Ajaran 2014/2015. Jurnal Elektronik Pembelajaran Matematika, 4(8), 781-792.

Ulya, H., Kartono, \& Retnoningsih, A. (2014). Analysis of Mathematics Problem Solving Ability of Junior High School Students Viewed From Students' Cognitive Style. International Journal of Education and Research, 2(10), 577-582.

Ulya, H., \& Rahayu, R. (2017). Pembelajaran Etnomatematika Untuk Menurunkan Kecemasan Matematika. Jurnal Mercumatika, 2(1), 16-23.

Wati, M. K., \& Sujadi, A., A. (2017). Analisis Kesalahan dalam Menyelesaikan Masalah Matematika dengan Menggunakan Langkah Polya Siswa Kelas VII SMP. Jurnal Prisma, 6(1), 9-16.

Yousefi, M. (2011). Cognitive Style and EFL Learners' Listening Comprehension Ability. Indonesian Journal of Applied Linguistics, 1(1), 78-83. 